Journal of

Entreprenuership and

Project Management

(JEPM)

INFLUENCE OF CORPORATE ENTREPRENEURSHIP ON PERFORMANCE OF STATE CORPORATIONS IN KENYA

DR.BRUNO MUGAMBI LINYIRU, DR.KABARE KARANJA AND DR.ROBERT GICHIRA

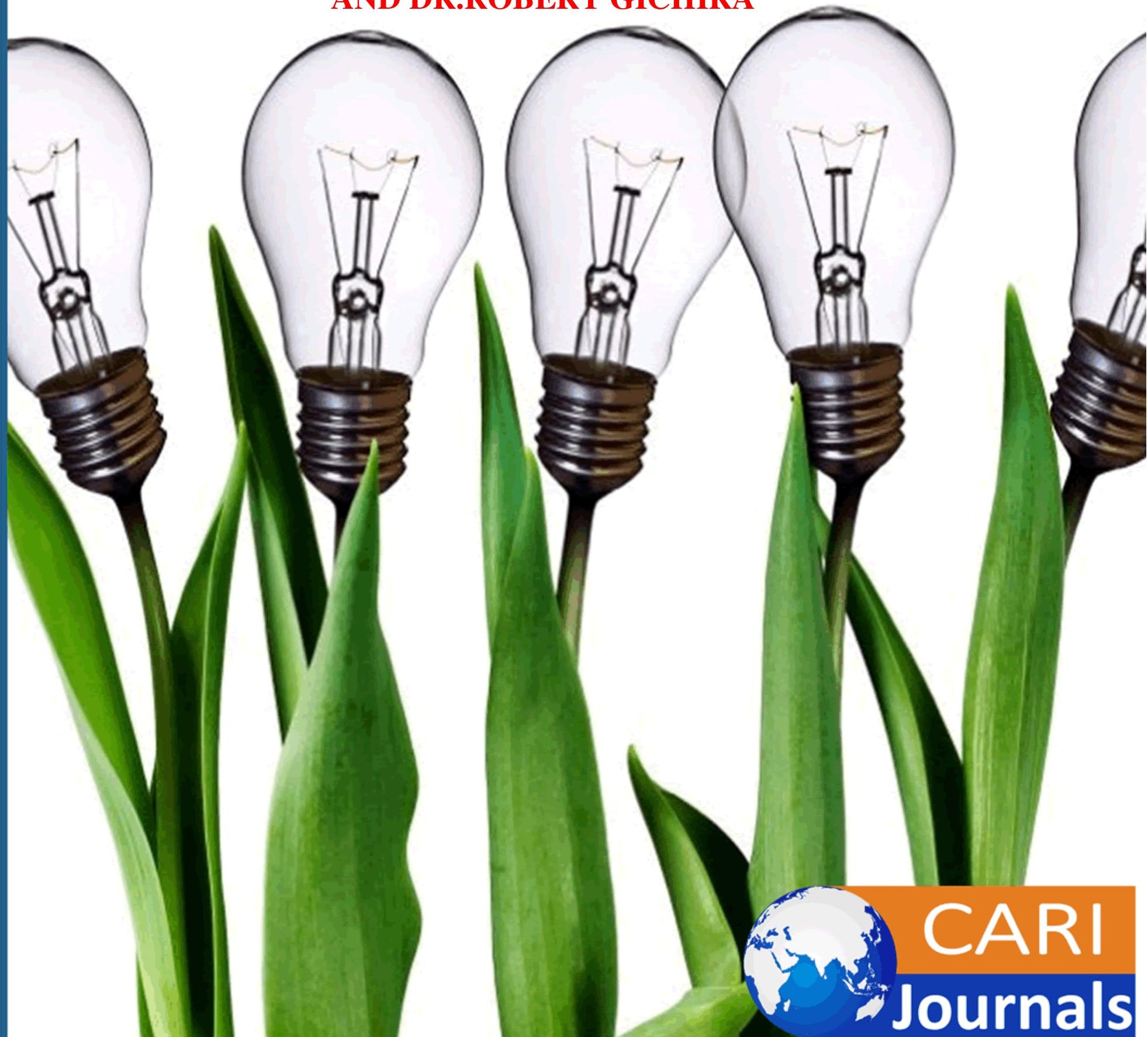




\title{
INFLUENCE OF CORPORATE ENTREPRENEURSHIP ON PERFORMANCE OF STATE CORPORATIONS IN KENYA
}

\author{
${ }^{* 1}$ Dr.Bruno Mugambi Linyiru \\ Doctorate student, Jomo Kenyatta University of Agriculture and Technology, Kenya \\ Corresponding email Address: blinyiru@ gmail.com \\ ${ }^{2}$ Dr.KabareKaranja \\ Lecturer, Jomo Kenyatta University of Agriculture and Technology, Kenya \\ ${ }^{3}$ Dr.RobertGichira \\ Lecturer, Jomo Kenyatta University of Agriculture and Technology, Kenya
}

\begin{abstract}
Purpose: The purpose of this study was to establish the influence of corporate entrepreneurship on performance of state corporations in Kenya.
\end{abstract}

Methodology: The study adopted an explanatory research design. The population of the research consists of the 187 state corporations in Kenya as at 2013. The unit of analysis was the state corporation. A purposive sample of 55 commercial state corporations was included in the study. The study used primary data gathered using questionnaires. Statistical Package for Social Sciences (SPSS) was used in the analysis of data. Reliability and validity tests were conducted to determine the internal consistencies of the variables under investigation. The data was analyzed by use of descriptive and inferential statistics. Descriptive statistics produced frequencies, trends, means and percentages while inferential statistics produced regression and correlation results which showed the causal relationship among the variables. Results were presented on frequency tables and charts.

Results: The study findings indicated that there was improved firm performance which was linked to corporate entrepreneurship. Results showed that companies initiated actions to which competitors responded to, the firms had a tendency to be ahead of other competitors in introducing novel idea or products and the companies strived in identifying new markets to sale products. Results indicated that risk taking, innovativeness, competitive aggressiveness and organizational factors were key determinants of firm performance for commercial state corporations in Kenya. The study findings also indicated that the companies had a strong tendency to increase the market share by reducing competitors through competitive marketing strategies, the companies spent substantial amount of financial resources in sales promotion and the companies actively searched for significant opportunities to improve market share.

Policy recommendation: The study recommends to the management of firms that corporate entrepreneurship should be pursued as a competitive and performance improvement strategy by all firms regardless of size. This is because corporate entrepreneurship influences firm performance positively. For corporate entrepreneurship to thrive, firms need to put in place an environment with support systems, structures and resources that encourage employees to behave entrepreneurially. The management should therefore ensure that they engage all the employees as they embrace corporate entrepreneurship to ensure that all staffs are working towards achieving the same objective and company goal. The study is a justification of the fact that an organization with competitive innovativeness skills has a deep understanding of 
the business enterprises which catapults their growth to a large extent. The study recommends that the management should use technology in controlling the production cost while maintaining competitive prices as it results in continued profitability of a firm and therefore growth. Managers should be efficient time managers with a control on the firm cost of operation to help provide a working schedule and competitive prices which fit the client needs.

\section{Keywords: Corporate entrepreneurship, performance, state corporations in Kenya}

\subsection{Introduction}

Corporate entrepreneurship (CE) is crucially important to the survival, profitability and growth of a company. This is due to the fact that CE activities tend to stimulate creativity and innovation as well as to encourage a culture of calculated risk-taking throughout organizational operations which may reinforce the company's position in existing markets by entering new and lucrative growth fields (Zahra, Filatotchev \& Wright, 2009). The corporate entrepreneurship elements in the established firms comprise the activities such as innovation, pro-activeness and risk-taking (Zahra, 1993). Empirically, several studies have been conducted on this issue especially in the case of developed countries. Focus of these studies was on the correlation between corporate entrepreneurship dimensions in different analysis scenarios. These include comparisons between countries (Antoncic\& Scarlet, 2008), between younger and matured companies (George, 2005; Antoncic and Scarlet, 2008; Aktan\&Bulut, 2008) and between manufacturing and non-manufacturing entities (Antoncic\& Scarlet, 2008).

Corporate entrepreneurship has been defined by researchers from several perspectives. Sharma and Chrisman (1999) for instance, defined corporate entrepreneurship as "a process whereby an individual or group of individuals in an established company attempts to create a new organization or to instigate renewal or innovation within the current organizational structure. Morris and Kuratko (2002), on the other hand, defined corporate entrepreneurship as a term used to describe the entrepreneurial behaviour inside an established organization. In some circumstances, the term has also been referred as corporate venturing or intrapreneurship (Zahra, 1991; Hornsby, Kuratko, \& Zahra, 2002). Additionally, the literature of corporate entrepreneurship has been seriously discussed in theoretical (Aktan\&Bulut, 2008) and field studies, in exploring its multidimensional structure such as risk-taking, innovativeness, pro-activeness and competitive aggressiveness (Lumpkin \& Dess, 1996; 2001; Sharma \& Chrisman, 1999). Crucially, Lassen (2007) posits that in order to survive, firms are required to continuously manage change and maintain flexibility, thus both fields of strategic management and entrepreneurship are envisaged to become increasingly intertwined.

The literature on the financial performance and dimensions of corporate entrepreneurship has shown that corporate entrepreneurship dimensions such as proactiveness, risk-taking, innovations and competitive aggressiveness significantly and positively influences the financial performance of the companies being investigated. Lassen (2007) investigated seven established high-tech firms that evolved to radical technological innovation. The radical innovation project, as suggested in the study, entails at least one of the following: (1) new to the world performance features; (2) signification improvement in known features (5times to 10 times); (3) significant reduction in losses (30\%-50\%). However, in order to obtain desired balance between entrepreneurial and strategic forces, incorporation of strategic considerations at several different levels of organization was found to be crucial. Subsequently, the study 
proposed a strategic entrepreneur model to be adopted by the firms. For data analysis, it looked at financial performance of the firms as a primary dependent variable against the level of entrepreneurship of the firm such as the effectiveness combination of autonomy, innovativeness, risk-taking, pro-activeness and competitive aggressiveness. The study emphasized the importance of the commercialization of products and technologies for enabling the firm to capture more value in the market.

Aktan and Bulut (2008) also examined the effects of four sub-dimensions of corporate entrepreneurship (pro-activeness, risk-taking, innovation, and competitive aggressiveness) against the financial performance of 312 firms. The study used return on investment (ROI), return on equity (ROE), growth of sales and market based measurement (economic value added, market value added) and concludes that all the correlation coefficients across the corporate entrepreneurship dimensions and the financial performance components are positive and significant. The findings demonstrate that all the four dimensions of corporate entrepreneurship examined impacts positively and significantly on financial performance.

\subsection{Statement of the problem}

In the constantly changing business environment companies tend to seek for new opportunities on the market where they can develop and sustain their competitive advantage and outperform competitors. In some environments, entrepreneurial orientation (risk taking, proactiveness, marketing aggressiveness, innovativeness and autonomy) of a firm leads to higher firm performance, and, thus, firms tend to be more entrepreneurial in order to improve their position on the market (Rauch et al., 2009). State corporations in Kenya have performed poorly compared to their private counterparts. Evidence of this is in the poor performance contracting results by majority of parastatals. Specifically, only a few commercially oriented corporations have reported profit or surplus. This is an economic problem that policy makers are still grappling with.

The problem of poor performance of commercial parastatals represents a drain on the exchequer and also results into non delivery on intended services. This has a negative implication on the welfare of Kenyan Citizens and may also imply that Vision 2030 is not met.

A few researches of $\mathrm{CE}$ in enterprises have been conducted in Africa, for example, Gantsho (2006) carried out an experimental study on how CE can be implemented in Development Finance Institutions in South Africa. The study only concentrated on how CE could be implemented in financial institutions and also did not address the issue of how to improve performance in such institutions. Nyanjom (2007) likewise researched on how enterprises in Botswana can develop and enhance entrepreneurial innovation and encourage entrepreneurial activity within enterprises. This study failed to address the obstacles affecting CE and enterprise characteristics at a global level.

In Kenya, many studies (Lwamba, Bwisa and Sakwa, 2014; Mokaya, 2012; Mayaka, 2006; Ongore and K'Obonyo, 2011; Miring'u and Muoria, 2011; Mang'unyi, 2011) have been conducted on factors that influence performance of enterprises; however, they fail to address commercial state corporations. For example, Mayaka (2006) in their studies of leading Kenya companies concentrated on the factors that lead to the companies' success in order to develop a case study. Hence, the studies failed to identify CE dimensions that lead to good performance of the enterprises and specifically commercial state corporations. 
This study established the effect of CE on the performance of state corporations in Kenya. Existing studies cover developed and emerging countries while most of the studies done in Kenya did not address corporate entrepreneurship in the state corporations in Kenya. There has also been little consensus on how state corporations generally reacted to various dimensions of corporate entrepreneurship. These are the gaps that the study wishes to address.

\subsection{Research Objectives}

i. To find out the influence of pro activeness on performance of state corporations in Kenya

ii. To determine the influence of risk taking on performance of state corporations in Kenya

iii. To evaluate the influence of innovativeness on performance of state corporations in Kenya

iv. To establish the influence of competitive aggressiveness on performance of state corporations in Kenya

v. To determine the influence of organization factors on the performance of state corporations in Kenya.

\subsection{LITERATURE REVIEW}

\subsection{Theoretical review}

\subsubsection{Schumpeterian Theory on Innovations}

Schumpeter's (1934) theory of innovative profits emphasized the role of entrepreneurship (his term was entrepreneurial profits) and the seeking out of opportunities for novel value and generating activities which would expand (and transform) the circular flow of income through risk taking, pro activity by the enterprise leadership and innovation which aims at fostering identification of opportunities through intellectual capital of entrepreneur to maximize the potential profit and growth.

Schumpeterian growth theory goes beyond economist theory by distinguishing explicitly between physical and intellectual capital, and between saving, which makes physical capital grow, and innovation, which makes intellectual capital grow. It supposes that technological progress comes from innovations carried out by firms motivated by the pursuit of profit, and that it involves what Schumpeter called "creative destruction". That is, each innovation is aimed at creating some new process or product that gives its creator a competitive advantage over its business rivals; it does so by rendering obsolete some previous innovation; and it is in turn destined to be rendered obsolete by future innovations (Schumpeter, 1934).

Endogenous growth theory challenges this neoclassical view by proposing channels through which the rate of technological progress, and hence the long-run rate of economic growth, can be influenced by economic factors. It starts from the observation that technological progress takes place through innovations, in the form of new products, processes and markets, many of which are the result of economic activities. For example, because firms learn from experience how to produce more efficiently, a higher pace of economic activity 
can raise the pace of process innovation by giving firms more production experience. Also, because many innovations result from R\&D expenditures undertaken by profit-seeking firms, economic policies with respect to trade, competition, education, taxes and intellectual property can influence the rate of innovation by affecting the private costs and benefits of doing R\&D (Dinopoulos\& Thompson, 1998).

Schumpeter, as cited by Swedberg (2000), pointed out economic behavior is somewhat automatic in nature and more likely to be standardized, while entrepreneurship consists of doing new things in a new manner, innovation being an essential value. As economics focused on the external influences over organizations, he believed that change could occur from the inside, and then go through a form of business cycle to really generate economic change. He set up a new production function where the entrepreneur is seen as making new combinations of already existing materials and forces, in terms of innovation; such as the introduction of a new good, introduction of a new method of production, opening of a new market, conquest of a new source of production input, and a new organization of an industry (Casson, 2002). For Schumpeter, the entrepreneur is motivated by the desire for power and independence, the will to succeed, and the satisfaction of getting things done (Swedberg, 2000). He conceptualized 'creative destruction' as a process of transformation that accompanies innovation where there is an incessant destruction of old ways of doing things substituted by creative new ways, which lead to constant innovation (Aghion\& Howitt, 1992).

The entrepreneur's crucial significance to the dynamics of the capitalist system flows from the fact that it is the entrepreneur's innovations that disrupt the economy and move it forward from one equilibrium to the other. Rather than adapting to external pressures, the entrepreneur destroys the static equilibrium from within the system by inventing new products, processes or behaviors that contrast the routine systems and activities (McDaniel, 2005; Drejer, 2004).

\subsubsection{Theories of Entrepreneurship}

Theory of entrepreneurship is a psychological approach, necessary to understand entrepreneurship. It argues that any theory of entrepreneurship should use active actions as a starting point - entrepreneurship is the epitome of an active agent in the market (rather than a reactive agent). The term entrepreneur originally meant an owner-manager, often the founder of business, the man who combined land, labour and capital for productive use. It is now sometimes used to refer to the innovative manager, who may or may not be the owner, or for the manager who makes crucial decisions for the company (Dale, 1987). According to Petrin (1997) entrepreneurship is defined variously so that to some, entrepreneurship means primarily innovation, to others it means risk-taking, while to others, a market stabilizing force and to others still, it means starting, owning and managing a small business. Quoting from Tyson, Petrin and Rogers (1994), Petrin (1997) adds that the entrepreneur is viewed as a person who either creates new markets, finds new sources of supply and new organizational forms; or as a person who is willing to take risks; or a person who, by exploiting market opportunities, eliminates disequilibrium between aggregate supply and aggregate demand, or as one who owns and operates a business. EO therefore encompasses creation of new combinations of production factors, new markets, and new sources of supply and new organizational forms.

Two theories of entrepreneurship are advanced for this study: the discovery theory and the creative theory of entrepreneurship. 


\subsection{METHODOLOGY}

The study adopted an explanatory research design. The population of the research consists of the 187 state corporations in Kenya as at 2013. The unit of analysis was the state corporation. A purposive sample of 55 commercial state corporations was included in the study. The study used primary data gathered using questionnaires. Statistical Package for Social Sciences (SPSS) was used in the analysis of data. Reliability and validity tests were conducted to determine the internal consistencies of the variables under investigation. The data was analyzed by use of descriptive and inferential statistics. Descriptive statistics produced frequencies, trends, means and percentages while inferential statistics produced regression and correlation results which showed the causal relationship among the variables. Results were presented on frequency tables and charts.

\subsection{RESULTS FINDINGS}

\subsection{Descriptive Analysis}

The second objective of the study was to determine the influence of risk taking on performance of state corporations in Kenya. Table 1 shows $68.9 \%$ of the respondents agreed that relative to their competitors, their company had higher propensity to take risks, $64.4 \%$ agreed that their company has shown a great deal of tolerance for high risk projects and $53.3 \%$ agreed that the top managers of their firm favour, a bold, aggressive posture in order to maximize the probability of exploiting potential when faced with uncertainty. Forty two point two percent of the respondents neither agreed nor disagreed that most people in their organization are willing to take risks, $42.3 \%$ agreed that their organization supports many small and experimental projects realizing that some will undoubtedly fail and $46.7 \%$ agreed that the term "risk taker" is considered a positive attribute for people. The mean score for responses for this section was 3.27 which indicates that majority of the respondents agreed that risk taking was a key driver of firm performance.

The findings are supported by those of Miller (1983) and Wang (2008) who argued that risktolerant and innovative firms' managers encourage new ways of thinking - tolerating mistakes and rewarding individuals with new ideas that contribute to innovation and business improvement. The culture of allowing individuals to making mistakes when trying new ways of improving business performance promotes a sense of open-mindedness (Moreno and Casillas, 2008). 
Journal of Entrepreneurship and Project Management (JEPM)

ISSN 2520 - 9116 (Online)

Vol. 2, Issue No. 1, pp 20 - 42, 2016

Table 1: Risk Taking and Performance Descriptive Analysis

\begin{tabular}{|c|c|c|c|c|c|c|}
\hline Statement & $\begin{array}{l}\text { Strongly } \\
\text { Disagree }\end{array}$ & $\begin{array}{c}\text { Disag } \\
\text { ree }\end{array}$ & $\begin{array}{c}\text { Neutr } \\
\text { al }\end{array}$ & Agree & $\begin{array}{c}\text { Strongly } \\
\text { Agree }\end{array}$ & $\begin{array}{l}\text { Likert } \\
\text { Mean }\end{array}$ \\
\hline $\begin{array}{l}\text { Relative to our competitors, our } \\
\text { company has higher propensity } \\
\text { to take risks }\end{array}$ & $4.4 \%$ & $13.3 \%$ & $13.3 \%$ & $55.6 \%$ & $13.3 \%$ & 3.6 \\
\hline $\begin{array}{l}\text { Our company has shown a great } \\
\text { deal of tolerance for high risk } \\
\text { projects }\end{array}$ & $4.4 \%$ & $17.8 \%$ & $13.3 \%$ & $51.1 \%$ & $13.3 \%$ & 3.51 \\
\hline $\begin{array}{l}\text { The top managers of my firm } \\
\text { favour, a bold, aggressive } \\
\text { posture in order to maximize } \\
\text { the probability of exploiting } \\
\text { potential when faced with } \\
\text { uncertainty }\end{array}$ & $4.4 \%$ & $17.8 \%$ & $24.4 \%$ & $51.1 \%$ & $2.2 \%$ & 3.29 \\
\hline $\begin{array}{l}\text { Most people in this } \\
\text { organization are willing to take } \\
\text { risks }\end{array}$ & $4.4 \%$ & $24.4 \%$ & $42.2 \%$ & $26.7 \%$ & $2.2 \%$ & 2.98 \\
\hline $\begin{array}{l}\text { This organization supports } \\
\text { many small and experimental } \\
\text { projects realizing that some will } \\
\text { undoubtedly fail }\end{array}$ & $8.9 \%$ & $22.2 \%$ & $26.7 \%$ & $35.6 \%$ & $6.7 \%$ & 3.09 \\
\hline $\begin{array}{l}\text { The term "risk taker" is } \\
\text { considered a positive attribute } \\
\text { for people }\end{array}$ & $6.7 \%$ & $26.7 \%$ & $20.0 \%$ & $37.8 \%$ & $8.9 \%$ & 3.16 \\
\hline Average & $5.5 \%$ & $20.4 \%$ & $23.3 \%$ & $43.0 \%$ & $7.8 \%$ & 3.27 \\
\hline
\end{tabular}

\subsubsection{Relationship between Pro Activeness and Firm Performance}

Table 2 shows the correlation results which indicate that there was a positive and significant relationship between risk taking and firm performance. This was evidenced by the $\mathrm{p}$ value of 0.001 which is less that of critical value $(0.05)$

\section{Table 2: Relationship between Risk Taking and Firm Performance}

\begin{tabular}{llcc}
\hline Variable & & Firm performance & Risk taking \\
\hline Firm performance & Pearson Correlation & 1 & \\
& Sig. (2-tailed) & & \\
Risk taking & Pearson Correlation & 0.476 & 1 \\
& Sig. (2-tailed) & 0.001 & \\
\hline
\end{tabular}

Binary logistic regression was used to model relationship between risk taking and firm performance. Table 3 shows that risk taking was statistically associated with firm performance $(\mathrm{p}<0.018)$. An increase in risk taking practices increases the probability of having high firm performance by 3.496 times. The findings imply that those firms with high 
Journal of Entrepreneurship and Project Management (JEPM)

ISSN 2520 - 9116 (Online)

Vol. 2, Issue No. 1, pp 20 - 42, 2016

risk taking practices have higher chances of having higher firm performance as compared to those without or with low risk taking practices.

Table 3: Logistic Regression for Risk Taking

\begin{tabular}{lcccccccc}
\hline Variable & Beta & S.E. & Wald & df & Sig. & $\operatorname{Exp}(\mathbf{B})$ & $\begin{array}{c}\text { 95\% C.I. for EXP(B) } \\
\text { Lower }\end{array}$ & \begin{tabular}{c} 
Upper \\
\hline Risk taking
\end{tabular} \\
& 1.252 & 0.527 & 5.645 & 1 & 0.018 & 3.496 & 1.245 & 9.817 \\
Constant & -3.771 & 1.804 & 4.368 & 1 & 0.037 & 0.023 & & \\
\hline
\end{tabular}

\subsection{Innovativeness and Firm Performance}

\subsubsection{Reliability Tests}

Using Cronbach's Coefficient Alpha test on innovativeness and firm performance, a coefficient of 0.792 was found as shown in Table 4. These results corroborates findings by Saunders Lewis and Thornhill (2009) and Christensen, Johnson and Turner (2011) who stated that scales of 0.7 and above, indicate satisfactory reliability. Based on these recommendations, the statements under the innovativeness variable of this study were concluded to have adequate internal consistency, therefore, reliable for the analysis and generalization on the population.

Table 4: Reliability Test for Innovativeness

\begin{tabular}{lc}
\hline Variable & Innovativeness \\
\hline Number of items & 6 \\
Cronbach's Alpha & 0.792 \\
\hline
\end{tabular}

\subsubsection{Sampling Adequacy}

To examine whether the data collected was adequate and appropriate for inferential statistical tests such as the factor analysis, regression analysis and other statistical tests, two main tests were performed namely; Kaiser-Meyer-Olkin (KMO) Measure of Sampling Adequacy and Barlett's Test of Sphericity. For a data set to be regarded as adequate and appropriate for statistical analysis, the value of KMO should be greater than 0.5 (Field, 2000).

Findings in Table 1.5 showed that the KMO statistic was 0.660 which was significantly high; that is greater than the critical level of significance of the test which was set at 0.5 (Field, 2000). In addition to the KMO test, the Bartlett's Test of Sphericity was also highly significant (Chi-square $=93.273$ with 15 degree of freedom, at $p<0.05$ ). The results of the KMO and Bartlett's Test are summarized in Table 5. These results provide an excellent justification for further statistical analysis to be conducted.

Table 5: Innovativeness KMO Sampling Adequacy and Bartlett's Sphericity Tests

Kaiser-Meyer-Olkin Measure

Bartlett's Chi- Square

Bartlett's df

Bartlett's Sig. 


\subsubsection{Factor Analysis}

Factor analysis was conducted after successful testing of validity and reliability using KMO coefficient and cronbach alpha results. Factor analysis was conducted using Principal Components Method (PCM) approach. The extraction of the factors followed the Kaiser Criterion where an eigen value of 1 or more indicates a unique factor. Total Variance analysis indicates that the 6 statements on innovativeness and firm performance can be factored into 1 factor. The total variance explained by the extracted factor is $50.35 \%$ as shown in Table 6

\section{Table 6: Innovativeness Total Variance Explained}

\begin{tabular}{lcccccc} 
Component & \multicolumn{2}{c}{ Initial Eigenvalues } & \multicolumn{3}{c}{ Extraction Sums of Squared Loadings } \\
& Total & $\begin{array}{c}\text { \% of } \\
\text { Variance }\end{array}$ & $\begin{array}{c}\text { Cumulative } \\
\%\end{array}$ & Total & $\begin{array}{c}\% \text { of } \\
\text { Variance }\end{array}$ & $\begin{array}{c}\text { Cumulative } \\
\%\end{array}$ \\
\hline 1 & 3.021 & 50.352 & 50.352 & 3.021 & 50.352 & 50.352 \\
2 & 1.113 & 18.557 & 68.909 & & & \\
3 & 0.701 & 11.676 & 80.585 & & & \\
4 & 0.627 & 10.455 & 91.039 & & & \\
5 & 0.314 & 5.24 & 96.279 & & & \\
6 & 0.223 & 3.721 & 100 & & & \\
\hline
\end{tabular}

Extraction Method: Principal Component Analysis.

\subsubsection{Descriptive Analysis}

The third objective of the study was to evaluate the influence of innovativeness on performance of state corporations in Kenya. Table 7 shows $71.1 \%$ of the respondents agreed that their company frequently tries out new ideas, $64.4 \%$ agreed that their company was creative in its methods of operation and $73.4 \%$ agreed that their company seeks out new ways to do things. Fifty three point four percent of the respondents agreed that company's emphasis on developing new products, $51.1 \%$ agreed that their company spends on new product development activities and $57.7 \%$ agreed that their company invests in developing proprietary Technologies. The mean score for responses for this section was 3.55 which indicates that majority of the respondents agreed that innovativeness was a key determinant of firm performance.

The findings agree with those in Clark (2010) who found that companies that are clearly innovators based their focus on new innovations, the number of new innovations and levels of investment in new innovations. The findings are also supported by Venter et al (2008) who stated that at the centre of entrepreneurship is innovativeness. An organization that innovates is classified as being entrepreneurial. Entrepreneurial activities influence a company's commitment to innovation (Miller, 1983; Lumpkin and Dess, 1996) by offering innovative products and processes. According to Huseet al. (2005), innovation has become a source of international competitive advantage.

The study findings are consistent with those of Zahra and Garvis (2000) who stated that innovation can also lead to the development of key capabilities that can improve a firm's performance. They also put emphasis on the fact that innovation generates products, goods, processes, services and systems that can be used to meet customer needs and build a strong market position. Thus innovation can improve the firm's profitability and fuel its growth. 
Journal of Entrepreneurship and Project Management (JEPM)

ISSN 2520 - 9116 (Online)

Vol. 2, Issue No. 1, pp 20 - 42, 2016

Better profitability and sustainability are also realized from continuous innovation by the entrepreneurial organization.

\section{Table 7: Innovativeness and Firm Performance}

\begin{tabular}{|c|c|c|c|c|c|c|}
\hline Statement & $\begin{array}{l}\text { Strongly } \\
\text { Disagree }\end{array}$ & $\begin{array}{c}\text { Disag } \\
\text { ree }\end{array}$ & $\begin{array}{c}\text { Neutr } \\
\text { al }\end{array}$ & Agree & $\begin{array}{l}\text { Strongly } \\
\text { Agree }\end{array}$ & $\begin{array}{l}\text { Likert } \\
\text { Mean }\end{array}$ \\
\hline $\begin{array}{l}\text { Our company frequently tries } \\
\text { out new ideas }\end{array}$ & $0.0 \%$ & $17.8 \%$ & $11.1 \%$ & $57.8 \%$ & $13.3 \%$ & 3.67 \\
\hline $\begin{array}{l}\text { Our company is creative in its } \\
\text { methods of operation }\end{array}$ & $4.4 \%$ & $11.1 \%$ & $20.0 \%$ & $51.1 \%$ & $13.3 \%$ & 3.58 \\
\hline $\begin{array}{l}\text { Our company seeks out new } \\
\text { ways to do things }\end{array}$ & $0.0 \%$ & $13.3 \%$ & $13.3 \%$ & $66.7 \%$ & $6.7 \%$ & 3.67 \\
\hline $\begin{array}{l}\text { Company's emphasis on } \\
\text { developing new products }\end{array}$ & $0.0 \%$ & $20.0 \%$ & $26.7 \%$ & $46.7 \%$ & $6.7 \%$ & 3.4 \\
\hline $\begin{array}{l}\text { Our Company spends on new } \\
\text { product } \\
\text { activities }\end{array}$ & $4.4 \%$ & $6.7 \%$ & $37.8 \%$ & $40.0 \%$ & $11.1 \%$ & 3.47 \\
\hline $\begin{array}{ll}\text { Our company } & \text { Invests in } \\
\text { developing } & \text { proprietary } \\
\text { Technologies } & \end{array}$ & $0.0 \%$ & $20.0 \%$ & $22.2 \%$ & $44.4 \%$ & $13.3 \%$ & 3.51 \\
\hline Average & $1.5 \%$ & $14.8 \%$ & $21.9 \%$ & $51.1 \%$ & $10.7 \%$ & 3.55 \\
\hline
\end{tabular}

\subsubsection{Relationship between Innovativeness and Firm Performance}

Table 8 shows the correlation results which indicate that there was a positive and significant relationship between innovativeness and firm performance. This was evidenced by the $p$ value of 0.000 which is less that of critical value $(0.05)$

Table 8: Relationship between Innovativeness and Firm Performance

\begin{tabular}{llcc}
\hline Variable & & Firm performance & Innovativeness \\
\hline Firm performance & Pearson Correlation & 1 & \\
& Sig. (2-tailed) & & \\
Innovativeness & Pearson Correlation & 0.642 & 1 \\
& Sig. (2-tailed) & 0.000 & \\
\hline
\end{tabular}

Binary logistic regression was used to model relationship between innovativeness and firm performance. Table 9 shows that innovativeness was statistically associated with firm performance $(\mathrm{p}<0.002)$. An increase in innovativeness increases the probability of having high firm performance by 9.409 times. The findings imply that those firms with high innovativeness have higher chances of having higher firm performance as compared to those without or with low innovativeness. 
Journal of Entrepreneurship and Project Management (JEPM)

ISSN 2520 - 9116 (Online)

Vol. 2, Issue No. 1, pp 20 - 42, 2016

Table 9: Logistic Regression for Innovativeness

\begin{tabular}{lcccccccc}
\hline Variable & Beta & S.E. & Wald & $\begin{array}{l}\text { d } \\
\text { f }\end{array}$ & Sig. & $\begin{array}{c}\text { Exp(B } \\
)\end{array}$ & \multicolumn{2}{c}{$\begin{array}{c}\text { 95\% C.I. for } \\
\text { EXP(B) }\end{array}$} \\
& & & & & & & Lower & Upper \\
\hline Innovativeness & 2.242 & 0.731 & 9.399 & 1 & 0.002 & 9.409 & 2.245 & 39.435 \\
Constant & -7.419 & 2.573 & 8.312 & 1 & 0.004 & 0.001 & & \\
\hline
\end{tabular}

4.3 Competitive Aggressiveness and Firm Performance

\subsubsection{Reliability Tests}

Using Cronbach's Coefficient Alpha test on competitive aggressiveness and firm performance, a coefficient of 0.844 was found as shown in Table 10. These results corroborates findings by Saunders Lewis and Thornhill (2009) and Christensen, Johnson and Turner (2011) who stated that scales of 0.7 and above, indicate satisfactory reliability. Based on these recommendations, the statements under the competitive aggressiveness variable of this study were concluded to have adequate internal consistency, therefore, reliable for the analysis and generalization on the population.

Table 10: Reliability Test for Competitive Aggressiveness

\section{Variable}

Number of items

Cronbach's Alpha
Competitive Aggressiveness

6

0.844

\subsubsection{Sampling Adequacy}

To examine whether the data collected was adequate and appropriate for inferential statistical tests such as the factor analysis, regression analysis and other statistical tests, two main tests were performed namely; Kaiser-Meyer-Olkin (KMO) Measure of Sampling Adequacy and Barlett's Test of Sphericity. For a data set to be regarded as adequate and appropriate for statistical analysis, the value of KMO should be greater than 0.5 (Field, 2000).

Findings in Table 11 showed that the KMO statistic was 0.615 which was significantly high; that is greater than the critical level of significance of the test which was set at 0.5 (Field, 2000). In addition to the KMO test, the Bartlett's Test of Sphericity was also highly significant (Chi-square $=169.807$ with 15 degree of freedom, at $\mathrm{p}<0.05)$. The results of the KMO and Bartlett's Test are summarized in Table 1.23. These results provide an excellent justification for further statistical analysis to be conducted.

Table 11: Competitive Aggressiveness KMO Sampling Adequacy and Bartlett's Sphericity Tests

Kaiser-Meyer-Olkin Measure

Bartlett's Chi- Square

Bartlett's df

Bartlett's Sig. 


\subsubsection{Factor Analysis}

Factor analysis was conducted after successful testing of validity and reliability using KMO coefficient and cronbach alpha results. Factor analysis was conducted using Principal Components Method (PCM) approach. The extraction of the factors followed the Kaiser Criterion where an eigen value of 1 or more indicates a unique factor. Total Variance analysis indicates that the 6 statements on competitive aggressiveness and firm performance can be factored into 1 factor. The total variance explained by the extracted factor is $57.09 \%$ as shown in Table 12. The factor loading and communalities of the variable are shown in Appendix V.

\section{Table 12: Competitive Aggressiveness Total Variance Explained}

\begin{tabular}{|c|c|c|c|c|c|c|}
\hline \multirow[t]{2}{*}{ Component } & \multicolumn{3}{|c|}{ Initial Eigenvalues } & \multicolumn{3}{|c|}{$\begin{array}{c}\text { Extraction Sums of Squared } \\
\text { Loadings }\end{array}$} \\
\hline & Total & $\begin{array}{c}\% \text { of } \\
\text { Variance }\end{array}$ & $\begin{array}{c}\text { Cumulative } \\
\% \\
\end{array}$ & Total & $\begin{array}{c}\% \text { of } \\
\text { Variance }\end{array}$ & $\begin{array}{c}\text { Cumulative } \\
\%\end{array}$ \\
\hline 1 & 3.425 & 57.091 & 57.091 & 3.425 & 57.091 & 57.091 \\
\hline 2 & 0.96 & 15.995 & 73.087 & & & \\
\hline 3 & 0.848 & 14.138 & 87.225 & & & \\
\hline 4 & 0.561 & 9.351 & 96.576 & & & \\
\hline 5 & 0.117 & 1.958 & 98.534 & & & \\
\hline 6 & 0.088 & 1.466 & 100 & & & \\
\hline
\end{tabular}

Extraction Method: Principal Component Analysis.

\subsubsection{Descriptive Analysis}

The fourth objective of the study was to establish the influence of competitive aggressiveness on performance of state corporations in Kenya. Table 13 shows $93.4 \%$ of the respondents agreed that owing to the nature of the environment, bold, wide ranging acts are necessary to achieve the firm's objectives, $42.2 \%$ agreed that the company stimulates new demand on existing products in the current market through aggressive advertisement and $53.3 \%$ agreed that the company takes bold and wide ranging acts (e.g. sales, promotion, competitive prices and distributive channels) to market products. Thirty seven point eight percent of the respondents agreed that their company had a strong tendency to increase the market share by reducing competitors through competitive marketing strategies, $42.2 \%$ agreed that their company spends substantial amount of financial resources in sales promotion and $51.1 \%$ agreed that their company actively searches for significant opportunities to improve market share. The mean score for responses for this section was 3.33 which indicates that majority of the respondents agreed that competitive aggressiveness was a key determinant of firm performance.

The study findings agree with those in Dess, Lumpkin, and Eisner (2007) who asserted that firms which decide to gain share from competitive markets, adopt competitive aggressive behaviors by employing marketing strategies such as competing on price, increasing promotion and/or combating for the distribution channels or imitating the competitors' 
actions and/or products. By acting aggressive via marketing tools, they force relatively stronger competitors to make entry barriers for the current markets. The purposes of these bold and aggressive behaviors are initially to remain in competition and then to make profit by fulfilling the opportunities of markets.

Table 13: Competitive Aggressiveness and Firm Performance

\begin{tabular}{|c|c|c|c|c|c|c|}
\hline Statement & $\begin{array}{l}\text { Strongly } \\
\text { Disagree }\end{array}$ & $\begin{array}{c}\text { Disag } \\
\text { ree }\end{array}$ & $\begin{array}{c}\text { Neutr } \\
\text { al }\end{array}$ & Agree & $\begin{array}{c}\text { Strongly } \\
\text { Agree }\end{array}$ & $\begin{array}{l}\text { Likert } \\
\text { Mean }\end{array}$ \\
\hline $\begin{array}{l}\text { Owing to the nature of the } \\
\text { environment, bold, wide ranging } \\
\text { acts are necessary to achieve the } \\
\text { firm's objectives }\end{array}$ & $0.0 \%$ & $6.7 \%$ & $0.0 \%$ & $46.7 \%$ & $46.7 \%$ & 4.33 \\
\hline $\begin{array}{l}\text { The company stimulates new } \\
\text { demand on existing products in } \\
\text { the current market through } \\
\text { aggressive advertisement }\end{array}$ & $13.3 \%$ & $26.7 \%$ & $17.8 \%$ & $42.2 \%$ & $0.0 \%$ & 2.89 \\
\hline $\begin{array}{l}\text { The company takes bold and } \\
\text { wide ranging acts (e.g. sales, } \\
\text { promotion, competitive prices } \\
\text { and distributive channels) to } \\
\text { market products }\end{array}$ & $6.7 \%$ & $13.3 \%$ & $26.7 \%$ & $42.2 \%$ & $11.1 \%$ & 3.38 \\
\hline $\begin{array}{l}\text { Our company has a strong } \\
\text { tendency to increase the market } \\
\text { share by reducing competitors } \\
\text { through competitive marketing } \\
\text { strategies }\end{array}$ & $4.4 \%$ & $40.0 \%$ & $17.8 \%$ & $31.1 \%$ & $6.7 \%$ & 2.96 \\
\hline $\begin{array}{l}\text { Our company spends substantial } \\
\text { amount of financial resources in } \\
\text { sales promotion }\end{array}$ & $6.7 \%$ & $37.8 \%$ & $13.3 \%$ & $37.8 \%$ & $4.4 \%$ & 2.96 \\
\hline $\begin{array}{l}\text { Our company actively searches } \\
\text { for significant opportunities to } \\
\text { improve market share }\end{array}$ & $4.4 \%$ & $13.3 \%$ & $31.1 \%$ & $33.3 \%$ & $17.8 \%$ & 3.47 \\
\hline Average & $5.9 \%$ & $23.0 \%$ & $17.8 \%$ & $38.9 \%$ & $14.5 \%$ & 3.33 \\
\hline
\end{tabular}

\subsubsection{Relationship between Competitive Aggressiveness and Firm Performance}

Table 14 shows the correlation results which indicate that there was a positive and significant relationship between competitive aggressiveness and firm performance. This was evidenced by the $\mathrm{p}$ value of 0.000 which is less that of critical value $(0.05)$ 
Journal of Entrepreneurship and Project Management (JEPM)

ISSN 2520 - 9116 (Online)

Vol. 2, Issue No. 1, pp 20 - 42, 2016

Journals

Table 14: Relationship between Competitive Aggressiveness and Firm Performance

\begin{tabular}{llcc} 
Variable & Firm performance & $\begin{array}{c}\text { Competitive } \\
\text { Aggressiveness }\end{array}$ \\
\hline Firm performance & $\begin{array}{l}\text { Pearson Correlation } \\
\text { Sig. (2-tailed) }\end{array}$ & 1 & \\
$\begin{array}{l}\text { Competitive } \\
\text { aggressiveness }\end{array}$ & $\begin{array}{l}\text { Pearson Correlation } \\
\text { Sig. (2-tailed) }\end{array}$ & 0.654 & 1 \\
& & 0.000 & \\
\hline
\end{tabular}

Binary logistic regression was used to model relationship between competitive aggressiveness and firm performance. Table 15 shows that competitive aggressiveness was statistically associated with firm performance $(\mathrm{p}<0.020)$. An increase in competitive aggressiveness increases the probability of having high firm performance by 3.061 times. The findings imply that those firms with high competitive aggressiveness have higher chances of having higher firm performance as compared to those without or with low competitive aggressiveness.

Table 15: Logistic Regression for Competitive Aggressiveness

\begin{tabular}{|c|c|c|c|c|c|c|c|c|}
\hline \multirow[t]{2}{*}{ Variable } & \multirow[t]{2}{*}{ Beta } & \multirow[t]{2}{*}{ S.E. } & \multirow[t]{2}{*}{ Wald } & \multirow[t]{2}{*}{$\begin{array}{l}\mathbf{d} \\
\mathbf{f}\end{array}$} & \multirow[t]{2}{*}{ Sig. } & \multirow[t]{2}{*}{$\underset{)}{\operatorname{Exp}(B}$} & \multicolumn{2}{|c|}{$\begin{array}{l}\text { 95\% C.I. for } \\
\operatorname{EXP(B)}\end{array}$} \\
\hline & & & & & & & Lower & Upper \\
\hline $\begin{array}{l}\text { Competitive } \\
\text { aggressiveness }\end{array}$ & 1.119 & 0.48 & 5.423 & 1 & 0.02 & 3.061 & 1.194 & 7.846 \\
\hline Constant & -3.331 & 1.652 & 4.066 & 1 & 0.044 & 0.036 & & \\
\hline
\end{tabular}

\subsection{Organizational Factors}

\subsubsection{Reliability Tests}

Using Cronbach's Coefficient Alpha test on organizational factors and firm performance, a coefficient of 0.729 was found as shown in Table16. These results corroborates findings by Saunders Lewis and Thornhill (2009) and Christensen, Johnson and Turner (2011) who stated that scales of 0.7 and above, indicate satisfactory reliability. Based on these recommendations, the statements under the organizational factors variable of this study were concluded to have adequate internal consistency, therefore, reliable for the analysis and generalization on the population.

Table 16: Reliability Test for Organizational Factors

\begin{tabular}{lc} 
Variable & Organizational Factors \\
\hline Number of items & 7 \\
Cronbach's Alpha & 0.739 \\
\hline
\end{tabular}

\subsubsection{Sampling Adequacy}

To examine whether the data collected was adequate and appropriate for inferential statistical tests such as the factor analysis, regression analysis and other statistical tests, two main tests 
were performed namely; Kaiser-Meyer-Olkin (KMO) Measure of Sampling Adequacy and Barlett's Test of Sphericity. For a data set to be regarded as adequate and appropriate for statistical analysis, the value of KMO should be greater than 0.5 (Field, 2000).

Findings in Table 17 showed that the KMO statistic was 0.812 which was significantly high; that is greater than the critical level of significance of the test which was set at 0.5 (Field, 2000). In addition to the KMO test, the Bartlett's Test of Sphericity was also highly significant (Chi-square $=456.424$ with 21 degree of freedom, at $\mathrm{p}<0.05)$. The results of the KMO and Bartlett's Test are summarized in Table 17. These results provide an excellent justification for further statistical analysis to be conducted.

Table 17: Organizational Factors KMO Sampling Adequacy and Bartlett's Sphericity Tests

Kaiser-Meyer-Olkin Measure

Bartlett's Chi- Square

456.424

Bartlett's df

Bartlett's Sig.

\subsubsection{Factor Analysis}

Factor analysis was conducted after successful testing of validity and reliability using KMO coefficient and cronbach alpha results. Factor analysis was conducted using Principal Components Method (PCM) approach. The extraction of the factors followed the Kaiser Criterion where an eigen value of 1 or more indicates a unique factor. Total Variance analysis indicates that the 7 statements on organizational factors and firm performance can be factored into 1 factor. The total variance explained by the extracted factor is $82.48 \%$ as shown in Table 18.

Table 18: Organizational Factors Total Variance Explained

\begin{tabular}{lcccccc} 
Component & \multicolumn{3}{c}{ Initial Eigen values } & \multicolumn{3}{c}{$\begin{array}{c}\text { Extraction Sums of Squared } \\
\text { Loadings }\end{array}$} \\
& Total & $\begin{array}{c}\text { \% of } \\
\text { Variance }\end{array}$ & $\begin{array}{c}\text { Cumulative } \\
\%\end{array}$ & Total & $\begin{array}{c}\% \text { of } \\
\text { Variance }\end{array}$ & $\begin{array}{c}\text { Cumulative } \\
\%\end{array}$ \\
\hline 1 & 5.774 & 82.48 & 82.48 & 5.774 & 82.48 & 82.48 \\
2 & 0.699 & 9.979 & 92.458 & & & \\
3 & 0.192 & 2.742 & 95.2 & & & \\
4 & 0.129 & 1.84 & 97.04 & & & \\
5 & 0.119 & 1.697 & 98.738 & & & \\
6 & 0.072 & 1.028 & 99.766 & & & \\
7 & 0.016 & 0.234 & 100 & & & \\
\hline
\end{tabular}

Extraction Method: Principal Component Analysis.

\subsubsection{Descriptive Analysis}

The fifth objective of the study was to determine the influence of organization factors on the performance of state corporations in Kenya. Table 19 shows $55.6 \%$ of the respondents agreed that the company has a competitive culture, $48.9 \%$ agreed that the organization structure favours coordination and communication and $66.6 \%$ agreed that the company has engaged in 
strategic alliances to boost it performance. Forty eight point nine percent of the respondents agreed that the company was effective at lobbying the government and funding organizations for more resources, $84.5 \%$ agreed that the organization has well trained and competent work force, $66.7 \%$ agreed that the board of directors offers a adequate oversight and $73.4 \%$ agreed that their company has independent board committees in place to enhance effective monitoring. The mean score for responses for this section was 3.33 which indicates that majority of the respondents agreed that organizational factors were key determinant of firm performance.

The findings are consistent with those of Miring'u and Muoria (2011) who analyzed the effects of Corporate Governance on performance of commercial state corporations in Kenya. Using a descriptive study design, the study sampled 30 SCs out of 41 state corporations in Kenya and studied the relationship between financial performance, board composition and size. The study found a positive relationship between Return on Equity (ROE) and board compositions of all State Corporations.

The study findings further agree with those in Manderlier et al(2009) found that board size has a positive impact on operational efficiency, suggesting that a large number of directors positively influence the rationalization of operational costs.

Table 19: Organizational Factors and Firm performance

\begin{tabular}{lcccccc}
\hline & $\begin{array}{c}\text { Strongly } \\
\text { Disagree }\end{array}$ & $\begin{array}{c}\text { Disag } \\
\text { ree }\end{array}$ & $\begin{array}{c}\text { Neutr } \\
\text { al }\end{array}$ & $\begin{array}{c}\text { Agree } \\
\text { Statement }\end{array}$ & $\begin{array}{c}\text { Strongly } \\
\text { Agree }\end{array}$ & $\begin{array}{c}\text { Likert } \\
\text { Mean }\end{array}$ \\
\hline $\begin{array}{l}\text { The company has a competitive } \\
\text { culture }\end{array}$ & $0.0 \%$ & $17.8 \%$ & $26.7 \%$ & $37.8 \%$ & $17.8 \%$ & 3.56 \\
$\begin{array}{l}\text { The organization structure } \\
\text { favours Coordination and } \\
\text { communication }\end{array}$ & $0.0 \%$ & $22.2 \%$ & $28.9 \%$ & $37.8 \%$ & $11.1 \%$ & 3.38 \\
$\begin{array}{l}\text { The company has engaged in } \\
\text { strategic alliances to boost it } \\
\text { performance }\end{array}$ & $0.0 \%$ & $26.7 \%$ & $6.7 \%$ & $62.2 \%$ & $4.4 \%$ & 3.44 \\
$\begin{array}{l}\text { The company is effective at } \\
\text { lobbying the government and } \\
\text { funding organizations for more } \\
\text { resources }\end{array}$ & $0.0 \%$ & $24.4 \%$ & $26.7 \%$ & $26.7 \%$ & $22.2 \%$ & 3.47 \\
$\begin{array}{l}\text { The organization has well } \\
\text { trained and competent work } \\
\text { force }\end{array}$ & $0.0 \%$ & $2.2 \%$ & $13.3 \%$ & $66.7 \%$ & $17.8 \%$ & 4 \\
$\begin{array}{l}\text { The board of directors offers a } \\
\text { adequate oversight }\end{array}$ & $6.7 \%$ & $8.9 \%$ & $17.8 \%$ & $48.9 \%$ & $17.8 \%$ & 3.62 \\
$\begin{array}{l}\text { Our company has independent } \\
\text { board committees in place to } \\
\text { enhance effective monitoring. }\end{array}$ & $13.3 \%$ & $8.9 \%$ & $4.4 \%$ & $55.6 \%$ & $17.8 \%$ & 3.56 \\
\begin{tabular}{l} 
Average \\
\hline
\end{tabular} & $2.9 \%$ & $15.9 \%$ & $17.8 \%$ & $48.0 \%$ & $15.6 \%$ & 3.58 \\
\hline
\end{tabular}




\subsubsection{Relationship Between Organizational Factors and Firm Performance}

Table 20 shows the correlation results which indicate that there was a positive and significant relationship between organizational factors and firm performance. This was evidenced by the $\mathrm{p}$ value of 0.000 which is less that of critical value $(0.05)$

Table 20: Relationship between Organizational Factors and Firm Performance

\begin{tabular}{llcc} 
Variable & & Firm performance & Organizational Factors \\
\hline Firm performance & Pearson Correlation & 1 & \\
& Sig. (2-tailed) & & \\
Organizational Factors & Pearson Correlation & 0.624 & 1 \\
& Sig. (2-tailed) & 0.000 & \\
\hline
\end{tabular}

Binary logistic regression was used to model relationship between organizational factors and firm performance. Table 21 shows that organizational factors was statistically associated with firm performance $(\mathrm{p}<0.020)$. An increase in organizational factors effectiveness increases the probability of having high firm performance by 15.699 times. The findings imply that those firms with effective organizational factors have higher chances of having higher firm performance as compared to those without organizational factors.

Table 21: Logistic Regression for Organizational Factors

\begin{tabular}{lcccccccc}
\hline Variable & Beta & S.E. & Wald & $\begin{array}{l}\text { d } \\
\text { f }\end{array}$ & Sig. & $\operatorname{Exp(B)}$ & \multicolumn{2}{c}{$\begin{array}{c}\text { 95\% C.I. for } \\
\text { EXP(B) } \\
\text { Lower }\end{array}$} \\
\hline $\begin{array}{l}\text { Organizational } \\
\text { Factors }\end{array}$ & 2.754 & 0.888 & 9.619 & 1 & 0.002 & 15.699 & 2.755 & 89.453 \\
Constant & -9.305 & 3.134 & 8.814 & 1 & 0.003 & 0 & & \\
\hline
\end{tabular}

\subsection{Firm Performance}

\subsubsection{Reliability Tests}

Using Cronbach's Coefficient Alpha test on firm performance, a coefficient of 0.839 was found as shown in Table 22. These results corroborates findings by Saunders Lewis and Thornhill (2009) and Christensen, Johnson and Turner (2011) who stated that scales of 0.7 and above, indicate satisfactory reliability. Based on these recommendations, the statements under the firm performance variable of this study were concluded to have adequate internal consistency, therefore, reliable for the analysis and generalization on the population.

\section{Table 22: Reliability Test for firm performance}

\begin{tabular}{lc}
\hline Variable & Firm Performance \\
\hline Number of items & 6 \\
Cronbach's Alpha & 0.839 \\
\hline
\end{tabular}

\subsubsection{Descriptive Analysis}

The study sought to determine the performance of state corporations in Kenya. Table23 shows that $66.7 \%$ of the respondents agreed that their firm profitability has increased over the last five years, $48.9 \%$ agreed that their firm financial leverage has increased over the last five 
years and $80 \%$ agreed that their firm has experienced an increase in total revenue collected over the last 5 years. In addition, $86.7 \%$ of the respondents agreed that their firm has experienced an increase in assets over the last 5 years, $68.9 \%$ agreed that their firm has a higher market value and $71.1 \%$ agreed that the organization was more inclined to decisions that enhance returns on its physical capital rather than relational capital. The mean score for the responses was 3.68 which indicate that many employees agreed to the statements regarding firm performance.

Table 23: Firm Performance

\begin{tabular}{|c|c|c|c|c|c|c|}
\hline Statement & $\begin{array}{l}\text { Strongly } \\
\text { Disagree }\end{array}$ & $\begin{array}{c}\text { Disag } \\
\text { ree }\end{array}$ & $\begin{array}{c}\text { Neutr } \\
\text { al }\end{array}$ & Agree & $\begin{array}{l}\text { Strongly } \\
\text { Agree }\end{array}$ & $\begin{array}{l}\text { Likert } \\
\text { Mean }\end{array}$ \\
\hline $\begin{array}{l}\text { Our firm profitability has } \\
\text { increased over the last five years }\end{array}$ & $6.7 \%$ & $13.3 \%$ & $13.3 \%$ & $37.8 \%$ & $28.9 \%$ & 3.69 \\
\hline $\begin{array}{l}\text { Our firm financial leverage has } \\
\text { increased over the last five years }\end{array}$ & $11.1 \%$ & $13.3 \%$ & $26.7 \%$ & $26.7 \%$ & $22.2 \%$ & 3.36 \\
\hline $\begin{array}{l}\text { Our firm has experienced an } \\
\text { increase in total revenue } \\
\text { collected over the last } 5 \text { years }\end{array}$ & $6.7 \%$ & $13.3 \%$ & $0.0 \%$ & $51.1 \%$ & $28.9 \%$ & 3.82 \\
\hline $\begin{array}{l}\text { Our firm has experienced an } \\
\text { increase in assets over the last } 5 \\
\text { years }\end{array}$ & $6.7 \%$ & $6.7 \%$ & $0.0 \%$ & $71.1 \%$ & $15.6 \%$ & 3.82 \\
\hline $\begin{array}{l}\text { Our firm has a higher market } \\
\text { value }\end{array}$ & $0.0 \%$ & $20.0 \%$ & $11.1 \%$ & $46.7 \%$ & $22.2 \%$ & 3.71 \\
\hline $\begin{array}{l}\text { The organization is more inclined } \\
\text { to decisions that enhance returns } \\
\text { on its physical capital rather than } \\
\text { relational capital }\end{array}$ & $0.0 \%$ & $20.0 \%$ & $8.9 \%$ & $53.3 \%$ & $17.8 \%$ & 3.69 \\
\hline Average & $5.2 \%$ & $14.4 \%$ & $10.0 \%$ & $47.8 \%$ & $22.6 \%$ & 3.68 \\
\hline
\end{tabular}

\subsection{Multivariate Logistic Regression Analysis for Firm Performance (Overall Model)}

A multivariate logistic regression was used to model relationship between all independent variables and firm performance that were found significant in binary stage. Table 24 shows that pro activeness was statistically associated with firm performance $(\mathrm{p}<0.038)$. An increase in pro activeness increases the probability of having high firm performance by 8.196 times. The findings imply that those firms with high pro activeness have higher chances of having higher firm performance as compared to those without or with low pro activeness.

Table 24 shows that organizational factors was statistically associated with firm performance $(\mathrm{p}<0.005)$. An increase in organizational factors effectiveness increases the probability of having high firm performance by 34.422 times. The findings imply that those firms with effective organizational factors have higher chances of having higher firm performance as compared to those without organizational factors.

The study findings agreed with those of Lekmat and Selvarajah (2008) who examined the corporate entrepreneurship activity of senior managers in 400 auto-parts manufacturing 
companies randomly chosen from the Thailand Automotive Industry directory 2006-2007. The study suggested that corporate entrepreneurship has significant influence on firm performance in terms of financial aspects. Self renewal and organizational support were also found to be positively and significantly related to firm performance.

The study findings agree with those of Goosen et al. (2002) who used a three-factor key intrapreneurship model to study the significance of the financial outcomes towards company performance involving a sample of companies listed in the industrial sector of the Johannesburg Stock Exchange, South Africa. The results of the study support the hypothesis that corporate entrepreneurship dimensions such as innovativeness, pro-activeness and management's internal influence significantly contributes to financial performance.

Table 24: Multivariate Logistic Regression Analysis for Firm Performance

\begin{tabular}{|c|c|c|c|c|c|c|c|c|}
\hline \multirow[t]{2}{*}{ Variable } & \multirow[t]{2}{*}{ Beta } & \multirow[t]{2}{*}{ S.E. } & \multirow[t]{2}{*}{ Wald } & \multirow[t]{2}{*}{$\begin{array}{l}\text { d } \\
\mathbf{f}\end{array}$} & \multirow[t]{2}{*}{ Sig. } & \multirow[t]{2}{*}{$\operatorname{Exp}(B)$} & \multicolumn{2}{|c|}{$\begin{array}{l}\text { 95\% C.I. for } \\
\operatorname{EXP(B)}\end{array}$} \\
\hline & & & & & & & Lower & Upper \\
\hline Pro activeness & 2.104 & 1.012 & 4.324 & 1 & 0.038 & 8.196 & 1.129 & 59.517 \\
\hline Risk taking & -0.495 & 1.026 & 0.233 & 1 & 0.63 & 0.61 & 0.082 & 4.551 \\
\hline Innovativeness & 2.156 & 1.327 & 2.639 & 1 & 0.104 & 8.637 & 0.641 & 116.414 \\
\hline $\begin{array}{l}\text { Competitive } \\
\text { aggressiveness }\end{array}$ & -0.81 & 0.941 & 0.741 & 1 & 0.389 & 0.445 & 0.07 & 2.813 \\
\hline $\begin{array}{l}\text { Organizational } \\
\text { Factors }\end{array}$ & 3.539 & 1.274 & 7.713 & 1 & 0.005 & 34.422 & 2.833 & 418.257 \\
\hline Constant & -22.943 & 7.724 & 8.822 & 1 & 0.003 & 0 & & \\
\hline
\end{tabular}

\subsection{SUMMARY OF FINDINGS, CONCLUSIONS AND RECOMMENDATIONS}

\subsection{Summary of Findings}

The general objective of the study was to establish the influence of corporate entrepreneurship on performance of state corporations in Kenya. One of the key findings was that the directors at commercial state corporations were concerned with performance of the firms in Kenya. This was demonstrated by the extent of agreement with the statements in the questionnaire in support of firm performance of state corporations in Kenya. The findings indicated that there was improved firm performance which was linked to corporate entrepreneurship.

\subsection{Conclusions}

Based on the objectives and the findings of the study the following conclusion can be made. The intensive usage of corporate entrepreneurship in the enterprises generally increases the efficiency of doing business by creating new products and services, shortening the time to get to market, reducing the costs, decreasing the prices and more efficiently answering on the moves of the competitors and market changes. Therefore the strategic intention of managers of these enterprises should be a creation of new organizational climate based on the tighter cooperation between the individuals with the aim of achieving the synergic effects in internal entrepreneurial activities. 
Pro activeness was found to have an effect on firm performance. It can therefore be concluded that firms that nurture organizational structures and values conducive environment to entrepreneurial activities such as pro activeness are likely to experience better performance results.

Results also led to the conclusion that corporate entrepreneurship improves performance by increasing company's proactivity and willingness to take risks by pioneering the development of new products, processes and services. It can also be concluded that the firms have developed a mentality inclined to risk-taking activities.

Innovativeness had a positive effect on firm performance. It can therefore be concluded that firms are trying to be innovative and therefore, it can be said that innovativeness, as a dimension of corporate entrepreneurship, is a factor that has an influence on the performance of commercial state corporations. Results led to the conclusion that there is a stronger link between innovations and inventions of products and the company's performance in production companies, while service oriented companies are showing better results when compared with major competitors.

The study concludes that competitive aggressiveness has an effect on firm performance. Commercial state corporations that will apply and promote activities regarding corporate entrepreneurship can be sure that they will achieve significant competitive advantage and superior performance.

Organizational factors were statistically significant in explaining firm performance of commercial state corporations. It can therefore be concluded that for any firm to have better results should manage the organizational factors and nurture conducive environment for all employees to work in.

\subsection{Recommendations}

Based on the results, findings and conclusions the following recommendations have been deciphered. The study recommends to the management of firms that corporate entrepreneurship should be pursued as a competitive and performance improvement strategy by all firms regardless of size. This is because corporate entrepreneurship influences firm performance positively.

For corporate entrepreneurship to thrive, firms need to put in place an environment with support systems, structures and resources that encourage employees to behave entrepreneurially. The management should therefore ensure that they engage all the employees as they embrace corporate entrepreneurship to ensure that all staffs are working towards achieving the same objective and company goal.

The study is a justification of the fact that an organization with competitive innovativeness skills has a deep understanding of the business enterprises which catapults their growth to a large extent. The study recommends that the management should use technology in controlling the production cost while maintaining competitive prices as it results in continued profitability of a firm and therefore growth. Managers should be efficient time managers with a control on the firm cost of operation to help provide a working schedule and competitive prices which fit the client needs.

The study recommends that firms can increase the innovative capability of their firms by paying more attention towards learning orientation and entrepreneur orientation to improve 
performance. The investment in learning based capabilities and developing of entrepreneurial instinct to exploit opportunities plays a key role in the maintenance of innovativeness.

The findings of this study suggest that firms which aim at sustaining their competitive advantage have to enhance marketing activities to improve business performance. This proves that market oriented culture should enhance entrepreneurial behavior within the firm. In a competitive environment, aggressive marketing can strengthen performance. The market information obtained from customers and the competitors helps the firm to keep an eye on the market. These findings may be of help to managers of firms to intensify initiatives to encourage better understanding on the significance of corporate entrepreneurship and marketing orientation which boosts firm's competitive position and superior performance. This helps them to be more entrepreneurial and market oriented in order for the firms to survive the intensively competitive market environment.

\subsection{Areas for Further Study}

A replica of this study can be carried out with a further scope to include other state corporations and see whether the findings hold true. Future studies should apply different research instruments like interview guide, focus group discussions to involve respondents in discussions in order to generate detailed information which would help in bringing out better strategies for corporate entrepreneurship and performance of firms in Kenya.

\section{REFERENCES}

Agca, V. Topal, Y. and Kaya, H. (2009). Linking Intrapreneurship activities to multidimensional firm performance in Turkish manufacturing firms: an empirical study, International Entrepreneurship and Management Journal, 1-19

Aghion, P. and Howitt, P., (1992), A Model of Growth through Creative Destruction. Econometrica 60: $323-351$

Black, P. J., \&Wiliam, D. (2004). Towards coherence between classroom assessment and accountability: 103rd yearbook of the National Society for the Study of Education (part 2) (20-50). Chicago: University of Chicago Press.

Borg, D., \& Gall, R. (2007). Educational research: An introduction. Boston: Pearson Education.

Bowling, A. (1997). Research Methods in Health. Open University Press, Buckingham.

Broadbent M. \& Cullen J. (2005). Managing Financial Resources. Oxford: Elsevier Butterworth-Heinemann.

Bryman, A. \& Cramer, D. (1997). Quantitative Data Analysis with SPSS for Windows. Routledge, London

Burns, A., \& Groove, B. (2003). The Practice of Nursing Research: Conduct, critique \& utilization. $4^{\text {th }}$ edition. W. B. Saunders Company.

Clark, N. D. (2010). Innovation Management in SMMEs: Active Innovators in New Zealand, Journal of Small Business and Entrepreneurship, 23 (4), 601-619

Clark, N. D. (2010). Innovation Management in SMMEs: Active Innovators in New Zealand, Journal of Small Business and Entrepreneurship, 23 (4), 601-619 
Coates, B. (2007). Equity Bank, a Microfinance Service: Center for Social Innovation. Stanford, CA: Stanford University, Graduate School of Business.

Dinopoulos, E. \& Thompson, P. (1998). Schumpeterian growth without scale effect Journal of Economic Growth 3, 313-35.

Drejer, I. (2004). Identifying innovation in surveys of services: a Schumpetarian perspective. Research Policy 33, 2004, p. 551-562.

Guralnik and David B. (2004). Webster's New World College Dictionary, New York: A Simon \&Schusteer Macmillan Company.

Haniffa, R., \&Hudaib, M. (2006). Corporate Governance Structure and Performance of Malaysian Listed Companies. Journal of Business Finance \& Accounting, 33, 7/8, 1034- 1062.

Hornsby, J. S.; Naffziger, D. W.; Kuratko, D. F. \&Montagno, R. V. (1993). An interactive model of corporate entrepreneurship process. Entrepreneurship: Theory and practice, $29-37$.

Huse, M. Neubaum, D. O. and Gabrielsson, J. (2005). Corporate Innovation and Competitive Environment, International Entrepreneurship and Management Journal, 1(3), 313333

Jessen, J. R. (1978). Statistical survey techniques. Wiley. Retrieved $2^{\text {nd }}$ January 2011

Kaplan, R. S. \& Norton D. P. (2000). Having trouble with your strategy? Then map it. Harvard Business Review, (Sep-Oct), 167-176.

Kothari, C. (2004). Research Methodology: Methods \& Techniques, $2^{\text {nd }}$ edition. New age International Publishers, New Delhi, India

Lumpkin, G. T., \& Dess, G. G. (2001). Linking two dimensions of entrepreneurial orientation to firm performance. The moderating role of environment and industry life cycle. Journal of Business Venturing, 16(5), 429-451.

Lwamba, N.M, Bwisa, H \&Sakwa, M. (2014). Exploring the Effect of Corporate Entrepreneurship on Financial Performance of Firms: Evidence from Kenya's Manufacturing Firms. International Journal of Academic Research in Business and Social Sciences.

Manderlier, A., Bacq, S., Giacomin, O. \& Janssen, F. (2009). The Impact of South Asian Microfiance Institutions' Corporate Governance Mechanisms on thier Social and Financial performance: An Exploratory Study. Louvian: Centre for Reserch in Entreprenuerial Change \& Innovation Strategies.

Morris, M. H. \&Kuratko, D. F. (2002). Corporate Entrepreneurship. Mason, OH: SouthWestern College Publishers

Mugenda, O.M. \& Mugenda, A.G. (2003). Research Methods: Quantitative and QualitativeApproaches. Nairobi: African Centre for Technology Studies.

Romero-Martínez, A.M, Fernández-Rodríguez, Z., and Vázquez-Inchausti, E. (2010). Exploring corporate entrepreneurship in privatized firms. Journal of World Business, 45, 2-8. 
Särndal, C., Swensson, B., \&Wretman, J. (1992). Model Assisted Survey Sampling. Southport, United Kingdom: Springer-Verlag Publication.

Saunders, M., Lewis, P. \& Thornhill, A. (2009). Research methods for business students. (5th Edition). London: Prentice Hall.

Swedberg, R. (2000). Entrepreneurship. The Social Science View. Oxford: Oxford University Press.

Venkataraman, S. (1997). The distinctive domain of entrepreneurship research: An editor's perspective. In J. Katz \& J. Brockhaus (Eds.), Advances in entrepreneurship, firm emergence, and growth (pp. 119-138). Greenwich, CT: JAI Press.

Venter, A. Rwigema, H. and Urban, B. (2008). Entrepreneurship: theory in practice, 2nd edition, Oxford University Press Southern Africa (Pty) Ltd, Cape Town.

Wu, M.-C., Lin, H.-C., Lin, I.-C. \& Lai, C.-F. (2009). The effects of Corporate Governance on the Firm Performance. Changua: National Changua University of Eductaion.

Yermack, D. (1996). Higher market valuation of companies with a small board of directors. Journal of Financial Economics, 40, 2, 185-211.

Zahra, S. A. \&Garvis, D. M. (2000). International Corporate Entrepreneurship and Firm Performance: The Moderating Effect of International Environment Hostility, Journal of Business Venturing 15, 469-49. 